\title{
PENGATURAN SUHU TERHADAP PRODUKSI GAS METAN PADA REAKTOR BIOGAS
}

\author{
Oleh : \\ Aidil Zamri \\ Pengajar Teknik Mesin Politeknik Negeri Padang \\ E-mail : zamri_aidil@gmail.com
}

\begin{abstract}
Biogas is a gas fermentation of organic materials which contain most of the gas methane, carbon dioxide, few of carbon monoxide, hydrogen, hydrogen sulfide, nitrogen and ammonia. One of technological development of biogas production is anaerobic reactor. The processing of biogas technology is influenced by several factors, such as temperature and humidity. In this study, temperature is adjusted using a spiral system and biogas reactor which submerged into the water. The temperature of water can be controlled. In another case there is reactor without temperature setting as a comparison. The observation shows that the reactor in the water produces most biogas, reactor spiral in second place and reactor without heating in the last one.
\end{abstract}

Keywords : gas methane, biogas reactor and temperature

\section{PENDAHULUAN}

Setelah terjadinya krisis energi yang mencapai puncak pada dekade 1970, dunia menghadapi kenyataan bahwa persediaan minyak bumi, sebagai salah satu tulang punggung produksi energi terus berkurang. Bahkan beberapa ahli berpendapat, bahwa dengan pola konsumsi seperti sekarang, maka dalam waktu 50 tahun cadangan minyak bumi dunia akan habis [1](Pinske, 1993 dalam Salim, 2005). Pemanfaatan bio gas merupakan salah satu usaha untuk mengurangi kebergantungan masyarakat terhadap bahan bakar fosil yang tidak dapat diperbarui [2].(Judoamidjojo dkk., 1992).

Proses pembentukan gas metan pada reaktor biogas sangat tergantung pada perubahan suhu, pembentukan gas metan akan lebih cepat dua kali pada suhu $15^{\circ} \mathrm{C}$ dibandingkan pada suhu $35^{\circ} \mathrm{C}$ dan menghasilkan hampir 15 kali lebih banyak gas pada waktu proses yang sama. Menurut Khasristya dan Gracelon, J., Clark, J. (tanpa tahun), Suhu optimal yang baik untuk pengembangbiakan bakteri metanogenesis berkisar $30^{\circ} \mathrm{C}$ sampai $35^{\circ} \mathrm{C}$.

Pada penelitian ini, melihat dari permasalahan suhu yang akan menyebabkan kenaikan produksi gas metan hampir 15 kali lebih banyak. Kami akan meneliti dengan mempertahankan suhu $30^{\circ} \mathrm{C}$ sampai $35^{\circ}$ pada reaktor biogas dengan melakukan pemanasan disekeliling reaktor reaktor. Sehingga suhu yang berada didalam reaktor dapat dipertahankan.

\section{Biogas}

Biogas berasal dari proses penguraian bahan organik secara anaerobic (tanpa udara) oleh bakteri melalui tiga tahapan, yaitu hidrolisis, pengasaman,dan methanasi. Gambar proses pembentukan 
biogas dapat dilihat pada gambar 1. Secara garis besar proses pembentukan biogas dibagi menjadi tiga tahapan, yaitu: 1). Tahap Hidrolisis (Hydrolysis), 2) Tahap Asidifikasi (Acidogenesis dan Acetogenesis), dan 3) Tahap Pembentukan Gas Metana (Methanogenesis)

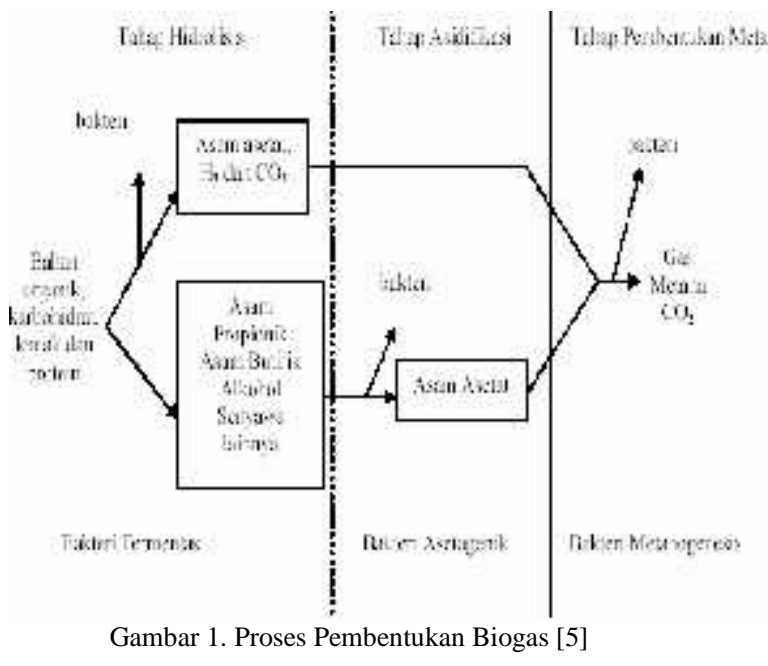

Bakteri-bakteri anaerob yang berperan dalam proses pembentukan biogas menurut Nurtjahya[6] antara lain, 1) Bakteri pembentuk asam (Acidogenik bakteria) yang merombak senyawa organik menjadi senyawa yang lebih sederhana, 2) Bakteri pembentuk asetat (acetogenic bacteria) yang merubah asam organik, dan senyawa netral yang lebih besar dari methanol menjadi asetat dan hydrogen. 3). Bakteri penghasil metan (metanogens), yang berperan dalam merubah asamasam lemak dan alkohol menjadi metan dan karbondioksida.

\section{Biodegester}

Ada beberapa jenis biodegester (reaktor penampung) biogas yang sering digunakan [7] antara lain, 1) Reaktor Kubah Tetap (Fixed Dome) Reaktor ini dibuat pertama kali di Cina sekitar tahun 1930-an, kemudian sejak saat itu reaktor ini berkembang dengan berbagai model. Reaktor ini memiliki dua bagian. Bagian pertama adalah digester sebagai tempat pencerna material biogas dan sebagai rumah bagi bakteri, baik bakteri pembentuk asam maupun bakteri pembentuk gas metana. Bagian kedua adalah kubah tetap (fixed dome). Dinamakan kubah tetap karena bentuknya menyerupai kubah dan bagian ini merupakan pengumpul gas yang tidak bergerak (fixed). 2) Reaktor Terapung (Floating Drum Reactor); Reaktor jenis terapung pertama kali dikembangkan di India pada tahun 1937. Reaktor ini memiliki bagian digester yang sama dengan reaktor kubah-tetap. Perbedaannya terletak pada bagian penampung gas yang menggunakan drum yang bergerak. Drum ini dapat bergerak naik-turun yang berfungsi untuk menyimpan gas. Pergerakan drum mengapung pada cairan tergantung dari jumlah gas yang dihasilkan. 3). Reaktor Balon (Balloon Reactor); Reaktor balon merupakan jenis reaktor yang banyak digunakan pada skala rumah tangga yang menggunakan bahan plastik sehingga lebih efisien dalam penanganan dan perubahan tempat biogas. Reaktor ini terdiri dari bagian yang berfungsi sebagai digester dan bagian penyimpan gas yang berhubungan tanpa sekat. Material organik terletak di bagian bawah karena memiliki berat yang lebih besar dibandingkan gas yang akan mengisi pada rongga atas.

Komponen yang digunakan untuk membuat biodegester tergantung pada jenis biodegester yang digunakan dan tujuan pembangunan biodegester. Menurut Suyitno [8], secara umum biodegester terdiri empat komponen utama sebagai berikut :
a. Saluran masuk Slurry (kotoran biodegester. segar). Saluran ini digunakan untuk memasukan slurry (campuran kotoran ternak dan air) ke dalam
b. Ruangan digestion (fermentasi). Runagan ini berfungsi tempat terjadinya proses fermentasi.
c. Saluran keluar residu (sludge). Berfungsi mengeluarkan kotoran 
yang telah mengalami proses fermentasi oleh bakteri.

d. Tangki penyimpanan biogas. Berfungsi untuk menyimpan gas yang dihasilkan dari proses fermentasi.

Proses fermentasi anaerob dapat berlangsung dengan optimal apabila populasi ketiga kelompok bakteri dalam keadaan seimbang. Bakteri-bakteri ini sangat sensitif terhadap perubahan lingkungan. Temperatur adalah salah satu faktor lingkungan yang utama, telah diketahui bahwa temperatur lingkungan ideal untuk fermentasi anaerobik berkisar pada $35^{\circ} \mathrm{C}$. Apabila temperatur berada jauh di bawah $35^{\circ} \mathrm{C}$, maka aktivitas bakteri akan menurun demikian pula produksi bio gas. Sebaliknya bila temperatur lingkungan berada jauh di atas $35^{\circ} \mathrm{C}$ maka beberapa jenis bakteri akan mati sehingga produksi bio gas juga akan menurun.

\section{METEDOLOGI}

\section{Perangkat Keras}

Pada penelitian ini dirancang dua macam biodigester yang dipanaskan, pertama dengan pemanasan luar (biodigester direndam didalam air), kedua dengan pemanasan dalam (didalam biodigester dialirkan air panas menggunakan pipa spiral), seperti terlihat pada gambar 2 .
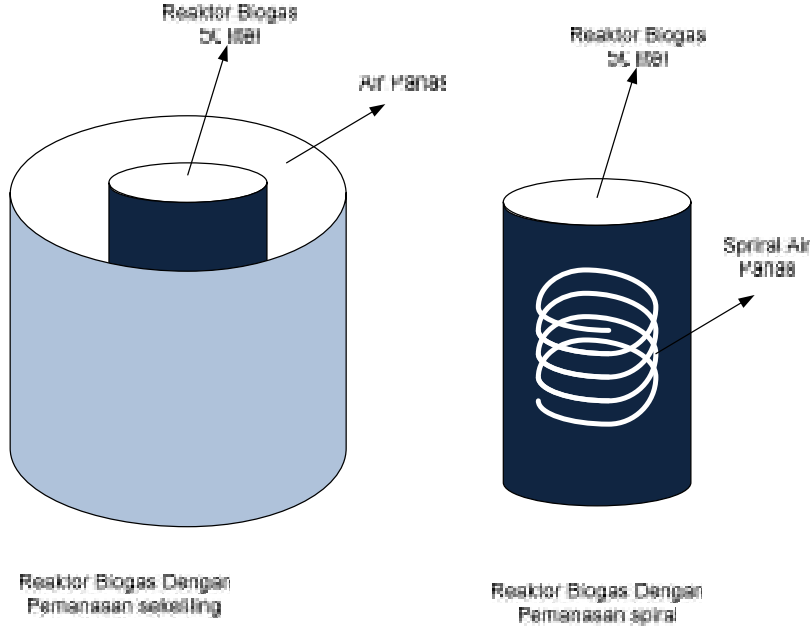

Gambar 2. Reaktor Biogas

\section{Sistem Sensor}

Sensor yang digunakan adalah sensor suhu PT100, sedangkan kendalinya menggunakan kendali ON/OFF.

\section{Sensor Ketinggian Level air}

Sensor level air terdiri dari tiga level yaitu rendah, sedang dan penuh. Setiap Level akan ditunjukan oleh nyala LED. Transistor gunakan sebagai saklar otomatis, jika permukaan air mengenai setiap kawat di tiap level maka arus akan lewat dan akan mengaktifkan saklar otomatis dan LED indicator akan menyala, seperti ditunjukkan gambar 3 .

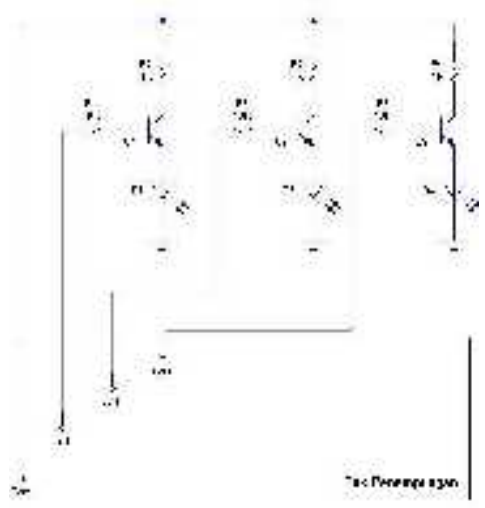

Gambar 3. Sensor Level Air

\section{Proses Pengujian}

Isian reaktor dari kotoran ternak. Kebutuhan awal isian untuk alat ini $2 / 3 \mathrm{x}$ 50 liter, yaitu 33,3 liter. Pencampuran bahan baku kotoran sapi dengan air dilakukan dengan perbandinagn $1: 1$. Selanjutnya, isian yang telah dibuat dimasukkan kedalam biodegester melalui 
corong masukan. Cara penggunaan secara lengkap adalah sebagai berikut:

1. Membuat bahan baku isian dengan mencampurkan kotoran sapi segar dengan air, perbandingan $1: 1$. Mengaduk kotoran sapi sampai merata kemudian menyaring campuran tersebut sambil membuang benda-benda keras yang mungkin tercampur.

2. Memasukkan bahan baku isian yang telah siap ke dalam ketiga reaktor melalui corong masukan. Pemasukan isian dihentikan setelah bahan isian sudah $2 / 3$ dari volume biodegester yaitu, $2 / 3 \times 50$ liter sekitar 33,3 liter yang terdiri 16,6 liter kotoran sapi dan 16,6 liter air, lalu tutup corong masukan ditutup.

3. Reaktor tanpa pemanas bantu siap dilakukan pengujian, sedangkan reaktor pemanasan dengan menggunakan wadah air dan dengan pipa spiral, maka dilakukan pengisian air kedalam wadah yang di isikan dari sumber air yang dikontrol oleh sensor ketinggian level air dan melakukan pengaliran air panas yang dimasukan melalui input air panas dan dikeluarkan memalui output air panas pada pipa spiral. Setalah itu reaktor ini siap dilakukan pengujian. Dan reaktor dengan pemanasan air, maka dilakukan dengan memasukan reaktor kedalam wadah air yang telah dibuat, lalu heater disambungkan kesumber listrik untuk memanaskan air. Selanjutnya reaktor pemanasan air siap dilakukan pengujian.

4. Pengambilan data dilakukan pada hari keenam. Data yang diambil dilakukan setiap jamnya yang dimulai pada pukul 09.00 WIB sampai 17.00 WIB. pengambilan data dilakukan empat kali penelitian.

\section{Hasil dan Pembahasan}

Proses pengambilan data dilakukan setelah 6 hari dari pengisian bahan isian, dikarenakan produksi gas yang dihasilkan dari fermentasi anaerob oleh biodegester dimulai pada 6 - 10 hari, hal ini sesuai dengan yang dinyatakan oleh Hadi (1990) yang menyatakan bahwa produksi biogas terbentuk sekitar 10 hari. Tabel 1. Produksi Gas Pada Reaktor Tanpa Kontrol Suhu

\begin{tabular}{|c|c|c|c|}
\hline Hari & Suhu & Pukul & Tekanan gas \\
\hline \multirow{9}{*}{7} & 28 & $09.00 \mathrm{WIB}$ & 19 \\
\hline & 28 & $10.00 \mathrm{WIB}$ & 19 \\
\hline & 32 & $11.00 \mathrm{WIB}$ & 20 \\
\hline & 32 & $12.00 \mathrm{WIB}$ & 20 \\
\hline & 35 & $13.00 \mathrm{WIB}$ & 22 \\
\hline & 36 & $14.00 \mathrm{WIB}$ & 25 \\
\hline & 36 & $15.00 \mathrm{WIB}$ & 25 \\
\hline & 33 & $16.00 \mathrm{WIB}$ & 23 \\
\hline & 31 & $17.00 \mathrm{WIB}$ & 25 \\
\hline \multirow{9}{*}{8} & 28 & 09.00 WIB & 20 \\
\hline & 28 & $10.00 \mathrm{WIB}$ & 26 \\
\hline & 32 & $11.00 \mathrm{WIB}$ & 30 \\
\hline & 32 & $12.00 \mathrm{WIB}$ & 30 \\
\hline & 35 & $13.00 \mathrm{WIB}$ & 31 \\
\hline & 36 & $14.00 \mathrm{WIB}$ & 33 \\
\hline & 36 & $15.00 \mathrm{WIB}$ & 33 \\
\hline & 33 & $16.00 \mathrm{WIB}$ & 31 \\
\hline & 31 & $17.00 \mathrm{WIB}$ & 30 \\
\hline \multirow{9}{*}{9} & 28 & 09.00 WIB & 21 \\
\hline & 28 & $10.00 \mathrm{WIB}$ & 29 \\
\hline & 32 & $11.00 \mathrm{WIB}$ & 30 \\
\hline & 32 & $12.00 \mathrm{WIB}$ & 35 \\
\hline & 35 & $13.00 \mathrm{WIB}$ & 36 \\
\hline & 36 & $14.00 \mathrm{WIB}$ & 36 \\
\hline & 36 & $15.00 \mathrm{WIB}$ & 36 \\
\hline & 33 & $16.00 \mathrm{WIB}$ & 36 \\
\hline & 31 & $17.00 \mathrm{WIB}$ & 34 \\
\hline \multirow{9}{*}{10} & 28 & $09.00 \mathrm{WIB}$ & 21 \\
\hline & 28 & $10.00 \mathrm{WIB}$ & 28 \\
\hline & 32 & $11.00 \mathrm{WIB}$ & 31 \\
\hline & 32 & $12.00 \mathrm{WIB}$ & 34 \\
\hline & 35 & $13.00 \mathrm{WIB}$ & 36 \\
\hline & 36 & $14.00 \mathrm{WIB}$ & 37 \\
\hline & 36 & $15.00 \mathrm{WIB}$ & 40 \\
\hline & 33 & $16.00 \mathrm{WIB}$ & 38 \\
\hline & 31 & 17.00 WIB & 33 \\
\hline
\end{tabular}

Tabel 2. Produksi Biogas Pada Reaktor Kontrol Suhu 


\begin{tabular}{|c|c|c|c|c|}
\hline \multirow[b]{2}{*}{ Hari } & \multirow[b]{2}{*}{ Pukul } & \multirow[b]{2}{*}{$\begin{array}{c}\text { Suhu } \\
\left({ }^{\circ} \mathrm{C}\right)\end{array}$} & \multicolumn{2}{|c|}{ Tekanan $(\mathrm{mmHg})$} \\
\hline & & & $\begin{array}{c}\text { reaktor } \\
\text { spiral }\end{array}$ & $\begin{array}{c}\text { reaktor } \\
\text { Pemanasan } \\
\text { Air }\end{array}$ \\
\hline \multirow{9}{*}{7} & $09.00 \mathrm{WIB}$ & \multirow{9}{*}{$\begin{array}{c}35- \\
38\end{array}$} & 46 & 20 \\
\hline & $10.00 \mathrm{WIB}$ & & 80 & 37 \\
\hline & 11.00 WIB & & 111 & 54 \\
\hline & $12.00 \mathrm{WIB}$ & & 116 & 60 \\
\hline & $13.00 \mathrm{WIB}$ & & 126 & 66 \\
\hline & $14.00 \mathrm{WIB}$ & & 145 & 70 \\
\hline & 15.00 WIB & & 143 & 77 \\
\hline & $16.00 \mathrm{WIB}$ & & 143 & 77 \\
\hline & $17.00 \mathrm{WIB}$ & & 138 & 70 \\
\hline \multirow{9}{*}{8} & $09.00 \mathrm{WIB}$ & \multirow{9}{*}{$\begin{array}{c}35- \\
38\end{array}$} & 110 & 18 \\
\hline & $10.00 \mathrm{WIB}$ & & 164 & 60 \\
\hline & $11.00 \mathrm{WIB}$ & & 184 & 66 \\
\hline & $12.00 \mathrm{WIB}$ & & 52 & 68 \\
\hline & $13.00 \mathrm{WIB}$ & & 76 & 121 \\
\hline & $14.00 \mathrm{WIB}$ & & 54 & 121 \\
\hline & 15.00 WIB & & 57 & 135 \\
\hline & $16.00 \mathrm{WIB}$ & & 36 & 130 \\
\hline & $17.00 \mathrm{WIB}$ & & 29 & 120 \\
\hline \multirow{9}{*}{9} & $09.00 \mathrm{WIB}$ & \multirow{6}{*}{$\begin{array}{c}35- \\
38\end{array}$} & 32 & 66 \\
\hline & $10.00 \mathrm{WIB}$ & & 50 & 80 \\
\hline & $11.00 \mathrm{WIB}$ & & 53 & 88 \\
\hline & $12.00 \mathrm{WIB}$ & & 56 & 92 \\
\hline & $13.00 \mathrm{WIB}$ & & 58 & 99 \\
\hline & $14.00 \mathrm{WIB}$ & & 65 & 109 \\
\hline & $15.00 \mathrm{WIB}$ & & 68 & 111 \\
\hline & $16.00 \mathrm{WIB}$ & & 68 & 119 \\
\hline & 17.00 WIB & & 69 & 115 \\
\hline \multirow{8}{*}{10} & $09.00 \mathrm{WIB}$ & \multirow{8}{*}{$\begin{array}{l}35- \\
38\end{array}$} & 79 & 111 \\
\hline & $10.00 \mathrm{WIB}$ & & 94 & 126 \\
\hline & $11.00 \mathrm{WIB}$ & & 102 & 138 \\
\hline & $12.00 \mathrm{WIB}$ & & 108 & 146 \\
\hline & 13.00 WIB & & 109 & 152 \\
\hline & $14.00 \mathrm{WIB}$ & & 113 & 160 \\
\hline & $15.00 \mathrm{WIB}$ & & 114 & 164 \\
\hline & $16.00 \mathrm{WIB}$ & & 114 & 169 \\
\hline
\end{tabular}

17.00 WIB

Dari tabel 1, didapat hubungan anatara suhu reaktor dengan hasil produksi gas. Seperti ditunjukkan pada gambar 4.

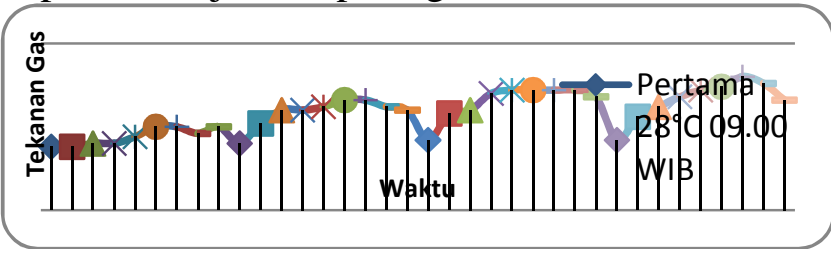

Gambar 4. Hubungan suhu fungsi produksi biogas.

Dari gambar grafik diatas dapat dilihat bahwa produksi gas tertinggi adalah pada penelitian keempat pada pukul 15.00 WIB, ini dikarenakan pada penelitian keempat ini reaktor sudah menhasilkan biogas dan pada pukul 15.00 WIB ini suhu lingkungan panas (tinggi) sehingga tekanan gas dalam biodegester ini meningkat. Tekanan gas terendah terdapat pada penelitian pertama yaitu pada pukul 09.00 WIB, karena pada waktu ini suhu lingkungan masih rendah sehingga pemanasan dalam reaktor sedikit, pemanasan yang sedikit membuat biodegester menghasilkan sedkit biogas sehingga tekanan gas rendah. Kenaikan dan penurunan tekanan gas dipengaruhi oleh suhu, semakin tinggi suhu lingkungan maka tekanan gasnya semakin tinggi dan sebaliknya jika suhu rendah maka otomatis tekanan gasnya menurun.

Dari tabel 2, diatas dapat dibuat grafik reaktor spiral dan grafik reaktor pemanasan air. Grafik tekanan reaktor spiral dan pemanasan air bisa dilihat pada gambar 5 dan gambar 6 .

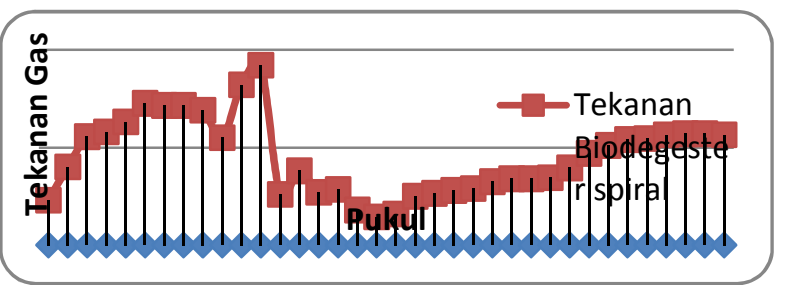


Gambar 5 Hubungan suhu dengan produksi Biogas Pada Reaktor Spiral

Dari gambar 5, tekanan gas tertinggi yang dicapai reaktor spiral terdapat pada pukul 11.00 WIB pada penelitian kedua, yaitu sebesar $184 \mathrm{mmHg}$. Tekanan gas yang diperoleh pada grafik ini penurunan dratis terdapat pada penelitian kedua, yaitu pada pukul 17.00 WIB sebesar 29 mmHg. Jadi tekanan gas pada biodegester spiral ini cenderung berubah karena pemanasan suhu dalam ruangan reaktor juga cenderung berubah.

Tekanan gas yang dihasilkan biodegester spiral mulai terjadi pada hari keenam (Pertama) pada pukul 09.00 WIB sebesar 46 mmgs. Hal ini berarti biogas telah dihasilkan pada hari keenam, yakni penelitian pertama pada pukul 09.00 WIB dan mencapai produk gas maksimum pada hari ketujuh, yakni penelitian kedua pada pukul 11.00 WIB sebesar $184 \mathrm{mmHg}$. Total tekanan gas sampai dengan hari kesembilan pada penelitian keempat pukul 17.00 WIB sebesar $3269 \mathrm{mmHg}$. Sehingga rataratanya sebesar $90,81 \mathrm{mmHg}$.

Dilihat dari grafik reaktor tanpa kontrol suhu, reaktor spiral lebih baik karena pemanasan yang dilakukan reaktor tidak mengikuti suhu lingkungan. Pemanasan dilakukan oleh spiral yang dialiri air panas secara terus-menerus.

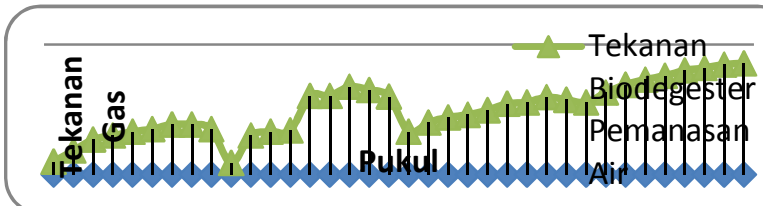

Gambar 6. Gambar 5 Hubungan suhu dengan produksi Biogas Pada Reaktor Pemanas Air

Dari gambar6, tekanan gas yang dihasilkan reaktor pemanasan air juga cendrung berubah, hal ini sesuai dengan pernyataan Sembiring (2004) bahwa sesudah produk mencapai maximum maka produk biogas akan menurun. Tekanan gas yang tertinggi yang dicapai reaktor ini terdapat pada penelitian keempat pada pukul 17.00 WIB. Tekanan gas naik pada penelitian keempat, karena produksi gas pada penelitian keempat ini tepatnya pada hari kedelapan sudah mulai mengisi biodegester, sesuai dengan pernyataan Hadi (1990) yang menyatakan bahwa produksi biogas terbentuk sekitar sepuluh hari.

Tekanan gas yang dihasilkan reaktor pemanasan air mulai terjadi pada pukul 09.00 WIB pada hari keenam (penelitian pertama) sebesar $20 \mathrm{mmHg}$. Hal ini berarti biodegester telah menghasilkan gas pada hari keenam pukul 09.00 WIB dan mencapai produk gas maksimum pada tekanan gas sebesar $169 \mathrm{mmHg}$. Total tekanan gas sampai hari penelitian terakhir pada pukul 17.00 WIB sebesar $3640 \mathrm{mmHg}$ sehingga rata-ratanya didapat sebesar 101,11 mmHg.

Dibandingkan dengan tekanan biodegester spiral, biodegster ini lebih menunjukan peningkatan biogas yang relatip stabil dan mempunyai rata-rata yang lebih tinggi. Jadi perbandingan rata-rata tekanan gas reaktor tanpa kontrol: Biodegester Spiral : Biodegester Pemanasan Air adalah 29,25 : 90,81 : $101,11=2,9: 9,1: 10,1$

Kesimpulan

1. Produksi biogas sangat berpengaruh terhadap perubahan suhu linngkungan maupun suhu yang berada didalam reaktor.

2. Reaktor yang paling banyak mengasilkan biogas dan dengan rata yang stabeil, adalah dengan kontrol suhu pemanasan air.

3. Kenaikan produksi gas pada pemansan air 5 kali lebih banyak jika tanpa pengontrolan suhu.

\section{Daftar Pustaka}

Hadi,N.,1981.Gas Bio sebagai bahan Bakar, Lemigas,Cepu 
Judoamidjojo, M., Darwis, A. A. dan Sa'id, E. G. (1992). Teknologi Fermentasi. CV Rajawali. Jakarta.

Kaltwasser, Bernd, 1980, Biogas ; Wiesbaden, FRG, pp. 35-36.

Khasristya Amaru, 2004. Rancangan Bangun dan Uji Kinerja Biodigester Plastik Polyethilene Skala kecil. Pertanian: UNPAD

Nurtjahya, Eddy, Dkk. 2003. Pemanfaatan Limbah Ternak Ruminansia untuk Mengurangi Pecemaran Lingkungan. Institute Pertanian Bogor: Bogor.

Said, Sjahruddin.2008.Membuat Biogas dari kotoran hewan. Jakarta: Bentara Simamora, S. 1989. Pengelolaan Limbah Peternakan (Animal Waste Management). Teknologi Energi Gasbio. Fakultas Politeknik Pertanian IPB. Bekerjasama dengan Direktora Pendidikan Menengah Kejuruan. Dirjen Pendidikan Dasar dan Menengah, Departemen P dan $\mathrm{K}$.

Simamora 2006. Meningkatkan kualitas Kompos. Agro Media pustaka. Jakarta.

Saputro, R.R.,2004,'Pembuatan Biogas Dari Limbah Peternakan",Undip Press ,Semarang.

Setiawan, A.Iwan. 1996. Memanfaatkan kotoran Ternak. Jakarta: Penebar Swadaya.
Sufyandi, A., 2001, "Informasi Teknologi Tepat Guna untuk Pedesaan Biogas",Bandung Suyitno.2010.TeknologiBiogas, Yogyakarta, Graha Ilmu.

Tiratsoo, E.N., 1979, Natural Gas Fuel For Future? A World Survey, Gulf Publishing Company, Houston Texas, Third Edition.

Wahyuni sri, Mp. 2008. Biogas. Jakarta: Penebar Swadaya.

Yunus muchammad. 1991. Pengelolahan Limbah Peternak. Universitas Brawijaya, Malang. 
ISSN :2085-6989

\section{HALAMAN INI \\ SENGAJA DIKOSONGKAN}

